\title{
DEVELOPMENT OF RELIGIOUS TOURISM IN MOSTAR TOURISM-GEOGRAPHICAL REGION
}

\author{
Aida Bidžan-Gekić ${ }^{24}$ \\ Lejla Žunićc ${ }^{25}$ \\ Haris Gekić ${ }^{26}$
}

\begin{abstract}
Religion has always been a powerful force that has attracted many tourists to destinations around the world. Our country is a place of meeting of different peoples and religions, which has contributed, according to the religious and cultural heritage, to be one of the richest countries in Europe. Four large religious communities in Bosnia and Herzegovina have significant shrines that are visited by tourists from all over the world, although neither the entities nor the states have a strategy for promoting religious tourism. In this paper we will present the representation of religious objects and manifestations of Mostar tourism-geographical region, their tourist valorization and proposal in order to improve this specific form of tourism.
\end{abstract}

Key words: Mostar; tourism-geographic region; tourist valorization; religious tourism; tourism development.

\section{INTRODUCTION}

"The concept of religion or faith implies conviction, trust and reliance" (Kesar, 2013). Historical development of tourism shows that religious travels are one of the oldest forms of tourism that arose from the increase of knowledge about the world, which was caused by the fact that people moved to different places where they could learn and inherit the aspects of other cultures, and they themselves find something about reality, spirituality, self-esteem and self-realization (Geić, 2002).

Religious Tourism, so-called "Faith Tourism", is a form of tourism, whereby people of faith travelindividually or in groups for reasons related to religion or spirituality

${ }^{24}$ Department of Geography, Faculty of Science, University of Sarajevo, Zmaja od Bosne 35, 71000 Sarajevo, Bosnia and Herzegovina, Email: aidabidzan@ gmail.com

${ }^{25}$ Department of Geography, Faculty of Science, University of Sarajevo, Zmaja od Bosne 35, 71000 Sarajevo, Bosnia and Herzegovina, Email: pmflejlazunic@yahoo.com

${ }^{26}$ Department of Geography, Faculty of Science, University of Sarajevo, Zmaja od Bosne 35, 71000 Sarajevo, Bosnia and Herzegovina, Email: hgekic@gmail.com 
in their quest for meaning. It could beunder, pilgrimage, missionary, or leisure purposes.

This tourism is one of the fastest growing segments of the travel industry. The UNWTO estimates that 300 million tourists visit the world's major religious sites each year (one fourth of all international tourist arrivals) and that 600 million national and international religious voyages are undertaken annually (UNWTO, 2016).

The problem of religious tourism in this region is the lack of sufficient accommodation capacities, the discordance of religious tourism with cultural tourism, and the lack of a detailed strategy for the development of religious tourism. The reason for the absence of a strategy of religious tourism in these regions is the lack of importance to religious tourism as it should be given, which would certainly enable the development of different branches of economy, and thus improve the living conditions at both the local and regional levels.

\section{MATERIALS AND METHODS}

The McKercher and Du Cross models of tourism valorization of sacral objects and events at Mostarregionwere applied (McKercher, B., du Cros, H., 2012). Identified tourist potentials and indicative parameters were evaluated on the Likert scale (1-5) to measure the tourist significance at the different spatial level. The indicative parameters of sacral objects and events included:

- Tourist-geographical position

- Ambience

- Attractiveness

- Compatibility

- Uniqueness

- The level of utilization for tourist purposes

- Two-season possibility of exploitation

- Construction / Equipment

- The representativeness

- Aesthetic / artistic value

- Tourist attendance 
The measured indicators were of great importance to understand the tourist significance of sacral objects and events which is important for their further tourist presentation. This way were determined the aesthetic and monumental qualities, uniqueness and cultural-historical importance, as well as their representativeness, which are the pulling tourism factors.

Quantitative approach resulted in calculation of general tourist value of each faith-tourism potential at Mostar tourism-geographical region and the ranking of the identified sacral objects and events according to the following criteria:

- 0 to 1.5 (inadequate quality and low market attractiveness) - are not suitable for tourist presentation and use;

- 1.5 to 2.5 (satisfactory quality and medium market attractiveness) - local tourist significance (L);

- 2.5 to 3.5 (good quality and good market attractiveness) - regional tourism significance $(\mathrm{R})$;

- 3.5 to 4.5 (very good quality and very good market attractiveness) - national tourist significance $(\mathrm{N})$, and

- 4.5 to 5 (excellent quality and high market attractiveness) - international tourist significance (I).

Scoring and rating of sacral objects and events was based on the zoning model where the Mostar tourism region was divided into three zones. The zero level has the best tourism-geographical position (downtown), it is mostly touristically attended, and therefore the majority of financial capital from local communities and government is invested exactly for the reconstruction and representation of tourist attractions in this zone, while the tourist significance of sacral objects decreases further from the center. The paper will consider only the sacral objects and events with their tourist significance above 3.5 (national and international rank of interest).

This detailed and complex analysis, classification and categorization of anthropogenic tourism potentials were made possible through the use of professional and scientific literature, which consisted of spatial plans at the state, entity, cantonal and municipal levels, then development plans and strategies (economic and tourism) of the cantons and municipalities, official websites of municipalities and tourist communities, as well as their own field research. 


\section{VALORIZATION OF THE ANTHROPOGENIC TOURIST POTENTIALS OF THE MOSTAR TOURISM-GEOGRAPHICALREGION FOR THE PURPOSE OF DEVELOPMENT OF RELIGIOUS TOURISM}

The Mostar tourism-geographicalregion covers $3.225 \mathrm{~km}^{2}$, from Makljen and IvanSedlo in the north to Mostarsko polje in the south. The tourist-geographical position of this region is very favorable because a significant Bosnian-Herzegovinian M-17 road crosses through it, connecting the capital ofBosnia and Herzegovina and the tourist center of this region with the Adriatic coast. Its position will be further improved once the $\mathrm{Vc}$ highway is built up, so for tourists coming to the capital will be easier tovisit this area. The Mostar tourism-geographicalregion consists of 5 municipalities: Jablanica, Konjic, Mostar, East Mostar and Prozor. The tourist center of this tourism-geographical region is Mostar, which is at the same time the political, economic, financial and cultural center of Herzegovina. The unique beauty of this region is contained in the fact that it is at the same time mountainous and lowland, both coastal and continental. In the areas around Jablanica, Konjic and Prozor there are rich geomorphological, biogeographical and hydrographical tourist potentials, which are preserved from anthropogenic pollution (Bidžan, 2015). 


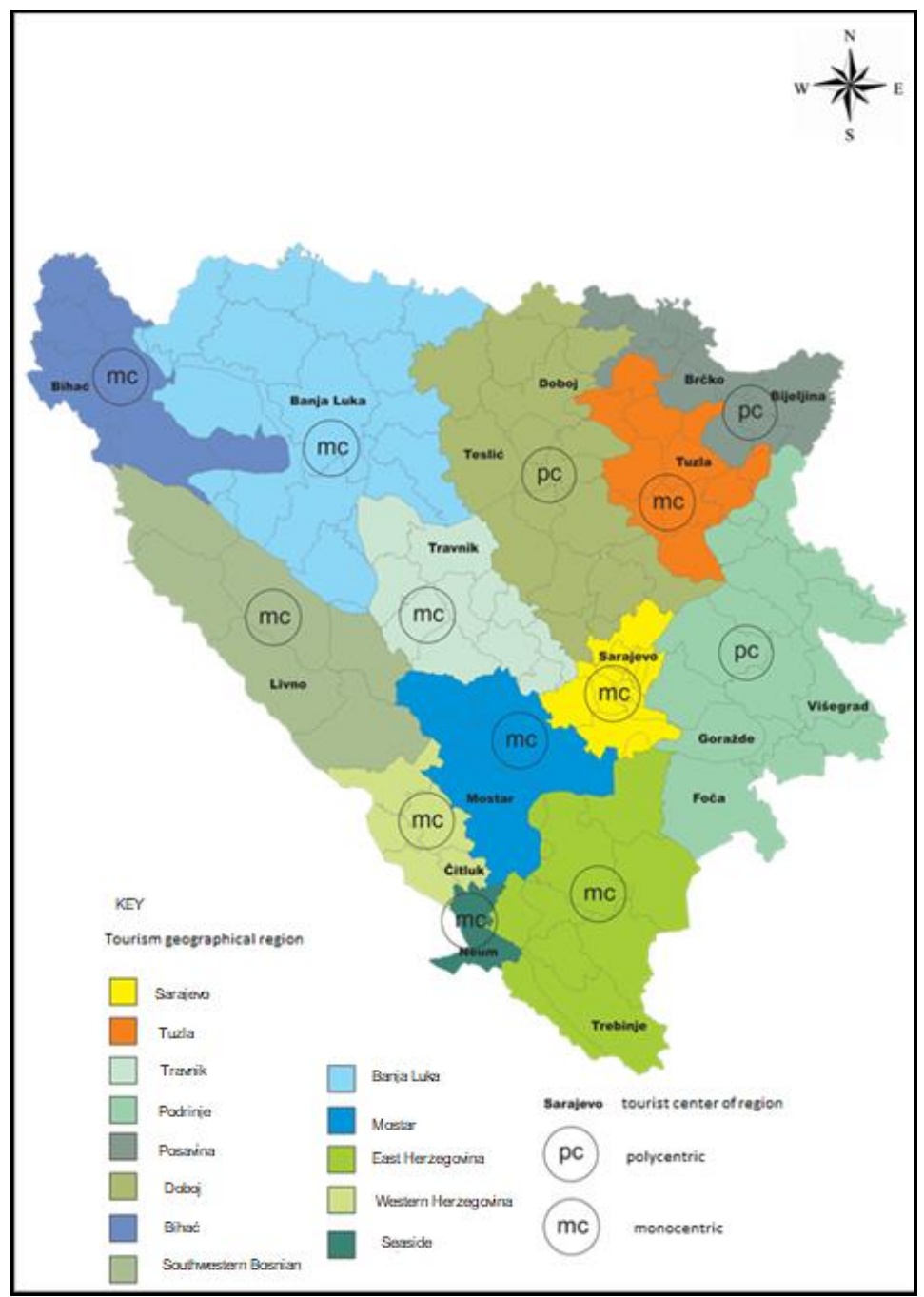

Fig 1.Tourism-geographical region of Bosnia and Herzegovina (Source: Bidžan, 2012)

This region according to preliminary data from the 2013 census has 166.987 inhabitants and the population density is 51.7 residence $/ \mathrm{km}^{2}$ (Institute for Statistics of the Federation of Bosnia and Herzegovina, 2013).

This region is connected to the Sarajevo tourism-geographical region and the Adriatic coastvia the M-17 (E73) highways, to Travnik region via M-16.2 and to the West-Herzegovina tourism-geographical region and the Republic of Croatia via regional road R-419 (Jablanica-Posušje), which in one part is still a macadam road. Through this region runs the Sarajevo-Mostar-Ploče (Republic of Croatia) normal trackrailway. In the city of Mostar there is also an international airport, which is of 
great importance for the future development of religious tourism in these region (Bidžan, 2015).

As far as tourist traffic is concerned, the Mostar tourism-geographical region in 2017 had a number of tourist arrivals of 270.810 , of which $17.9 \%$ weredomestic tourists, and82.1\% foreign tourists. They made 553.847 overnights, of which $17.2 \%$ were domestic and $82.8 \%$ foreign tourists. Most tourists come from South Korea, Italy, Poland, Croatia, Turkey, China, Slovenia, Serbia, Montenegro, Germany, Spain and France. Regarding accommodation capacity, this region offers 7.697 beds in various types and categories of accommodation (hotels, motels, small pensions, home accommodation and more) with a tendency of increasing tourist capacities and significant annual growth of tourist traffic (Institute for Statistics of the Federation of Bosnia and Herzegovina, 2018).

Mostar tourism-geographical region, according to its functionality, is a part of cognitive, educational and religious region. This tourism-geographical region has great significance for defining the tourist offer of Bosnia and Herzegovina, out of a total of 626 national monuments in Bosnia and Herzegovina, in the Mostar region there are 64 national monuments. Its unique natural and anthropogenic tourist potentials enable the development of numerous specific forms of tourism: bathing, sports-recreational, adventure, fishing, hunting, religious, cultural-manifestation, etc. Among the 64 national monuments, 34 monuments belong to sacral objects that can serve for the development of religious tourism (Commission for Preservation of National Monuments in Bosnia and Herzegovina, 2018; Bidžan, 2015). In Table 1, we will present the tourism valorization of the highest rated and at the same time the most important sacral objects of this tourism-geographical region, while the complete list can be viewed in the doctorate of A. Bidžan (2015), where all objects were covered. 
Table 1: Tourist valorization of sacral objects and religious events in the Mostar tourism-geographical region

\begin{tabular}{|c|c|c|c|c|c|c|c|c|c|c|c|c|c|c|}
\hline $\begin{array}{c}\text { Anthropogenic } \\
\text { tourist } \\
\text { potentials }\end{array}$ & 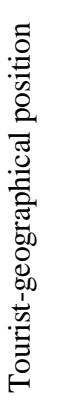 & 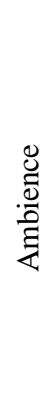 & : & 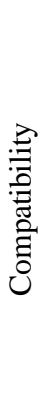 & 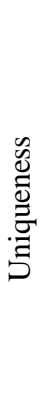 & 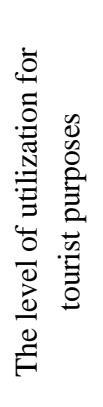 & 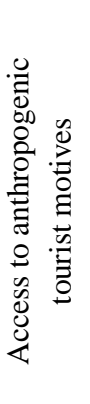 & 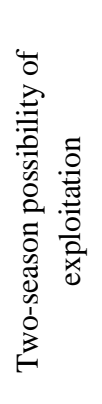 & 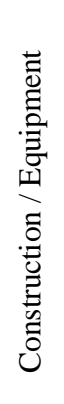 & 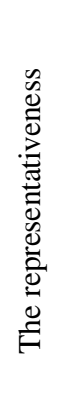 & 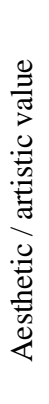 & 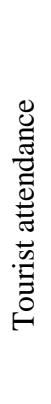 & 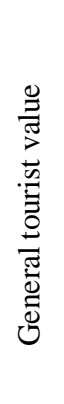 & 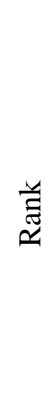 \\
\hline $\begin{array}{l}\text { 1. Franciscan } \\
\text { Monastery and } \\
\text { Church of the } \\
\text { Assumption of the } \\
\text { Blessed Virgin } \\
\text { Mary, Šćit, Prozor }\end{array}$ & 4 & 5 & 5 & 5 & 5 & 5 & 3 & 5 & 5 & 4 & 5 & 4 & 4,6 & I \\
\hline $\begin{array}{l}\text { 2. Nuhefendić } \\
\text { Mosque } \\
\text { (Čaršijska), } \\
\text { Prozor }\end{array}$ & 4,5 & 5 & 5 & 5 & 5 & 3 & 3,5 & 5 & 5 & 3,5 & 5 & 3 & 4,4 & $\mathrm{~N}$ \\
\hline $\begin{array}{l}\text { 3. Old Orthodox } \\
\text { Church, Mostar }\end{array}$ & 5 & 5 & 5 & 5 & 5 & 4 & 4 & 5 & 4 & 4 & 5 & 3 & 4,5 & I \\
\hline $\begin{array}{l}\text { 4. Tabačica } \\
\text { Mosque, Mostar }\end{array}$ & 4,5 & 5 & 5 & 5 & 5 & 2,5 & 3,5 & 5 & 2,5 & 2 & 5 & 2 & 3,9 & $\mathrm{~N}$ \\
\hline $\begin{array}{l}\text { 5. The Cloister of } \\
\text { the Franciscan } \\
\text { Monastery, } \\
\text { Mostar }\end{array}$ & 3 & 5 & 5 & 5 & 5 & 2,5 & 2,5 & 5 & 2,5 & 2 & 5 & 2 & 3,7 & $\mathrm{~N}$ \\
\hline $\begin{array}{l}\text { 6. Bishop's } \\
\text { Residence/Ordina } \\
\text { riate, Mostar }\end{array}$ & 4 & 5 & 5 & 5 & 5 & 4 & 4 & 5 & 4 & 4 & 5 & 4 & 4,5 & I \\
\hline $\begin{array}{l}\text { 7. Baba Beširova } \\
\text { Mosque in } \\
\text { Balinovac, Mostar }\end{array}$ & 4 & 5 & 5 & 5 & 5 & 2,5 & 3,5 & 5 & 3,5 & 2,5 & 5 & 2 & 4,0 & $\mathrm{~N}$ \\
\hline $\begin{array}{l}\text { 8. Karađoz-bey } \\
\text { Mosque, Mostar }\end{array}$ & 5 & 5 & 5 & 5 & 5 & 4 & 5 & 5 & 5 & 4 & 5 & 4 & 4,8 & I \\
\hline
\end{tabular}




\begin{tabular}{|c|c|c|c|c|c|c|c|c|c|c|c|c|c|c|}
\hline $\begin{array}{l}\text { 9. Karađoz-bey } \\
\text { Madrassa, Mostar }\end{array}$ & 4,5 & 5 & 5 & 5 & 5 & 3,5 & 4,5 & 5 & 3,5 & 3 & 5 & 2 & 4,3 & $\mathrm{~N}$ \\
\hline $\begin{array}{l}\text { 10. The } \\
\text { Cathedral of } \\
\text { Mary, Mother of } \\
\text { the Church, } \\
\text { Mostar }\end{array}$ & 5 & 5 & 5 & 5 & 5 & 3,5 & 4 & 5 & 3,5 & 4 & 5 & 4 & 4,5 & I \\
\hline $\begin{array}{l}\text { 11. Koski } \\
\text { Mehmed Pasha } \\
\text { Mosque, Mostar }\end{array}$ & 5 & 5 & 5 & 5 & 5 & 3,5 & 5 & 5 & 5 & 3 & 5 & 4 & 4,6 & I \\
\hline $\begin{array}{l}\text { 12. Koski } \\
\text { Mehmed Pasha } \\
\text { Madrassa, Mostar }\end{array}$ & 4,5 & 5 & 5 & 5 & 5 & 3,5 & 3,5 & 5 & 3,5 & 3 & 5 & 2 & 4,2 & $\mathrm{~N}$ \\
\hline 13. Tekke, Blagaj & 5 & 5 & 5 & 5 & 5 & 4 & 3,5 & 5 & 5 & 5 & 5 & 5 & 4,8 & $\mathrm{I}$ \\
\hline $\begin{array}{l}\text { 14. Monastery } \\
\text { Žitomislići, } \\
\text { Mostar }\end{array}$ & 4,5 & 5 & 5 & 5 & 5 & 3,5 & 4,5 & 5 & 3,5 & 4 & 5 & 4 & 4,5 & I \\
\hline $\begin{array}{l}\text { 15. Roznamedžija } \\
\text { Mosque, Mostar }\end{array}$ & 4,5 & 5 & 5 & 5 & 5 & 3,5 & 4,5 & 5 & 3,5 & 3 & 5 & 2 & 4,3 & $\mathrm{~N}$ \\
\hline $\begin{array}{l}\text { 16. Synagogue, } \\
\text { Mostar }\end{array}$ & 4,5 & 4 & 4 & 4 & 4 & 3,5 & 4,5 & 5 & 3,5 & 3 & 4 & 2 & 3,8 & $\mathrm{~N}$ \\
\hline $\begin{array}{l}\text { 17. Prkanjska } \\
\text { (Hadži Zulfikar) } \\
\text { Mosque, Konjic }\end{array}$ & 3,5 & 3,5 & 3,5 & 3,5 & 3,5 & 2,5 & 4,5 & 4 & 3,5 & 3 & 3,5 & 2 & 3,4 & $\mathrm{R}$ \\
\hline $\begin{array}{l}\text { 18. Repovačka } \\
\text { Mosque, Konjic }\end{array}$ & 4 & 3,5 & 3,5 & 3,5 & 3,5 & 3,5 & 3,5 & 4 & 3,5 & 3 & 3,5 & 2 & 3,4 & $\mathrm{R}$ \\
\hline $\begin{array}{l}\text { 19. "Dovište } \\
\text { Buna" }\end{array}$ & 5 & 5 & 5 & 5 & 5 & 4 & 4 & 1 & 5 & 5 & 5 & 5 & 4,5 & I \\
\hline $\begin{array}{l}\text { 20. Christmas } \\
\text { concerts }\end{array}$ & 5 & 5 & 5 & 5 & 5 & 4 & 4 & 1 & 5 & 5 & 5 & 5 & 4,5 & I \\
\hline
\end{tabular}

Source: Commission for Preservation of National Monuments in Bosnia and Herzegovina, 2018;Bidžan, 2015;

Legend:

- 0 to 1.5 (inadequate quality and low market attractiveness) - are not suitable for tourist presentation and use;

- 1.5 to 2.5 (satisfactory quality and medium market attractiveness) - local tourist significance $(\mathrm{L})$; 
- 2.5 to 3.5 (good quality and good market attractiveness) - regional tourism significance $(\mathrm{R})$;

- 3.5 to 4.5 (very good quality and very good market attractiveness) - national tourist significance $(\mathrm{N})$ and

- 4.5 to 5 (excellent quality and high market attractiveness) - international tourist significance (I).

Below, we will give a brief description of the religious buildings and the most significant religious-cultural manifestations, which received the highest total value for tourism valorization in the Mostar tourism-geographical region, and these are: Karađoz-bey Mosque and Koski Mehmed-Pasha Mosque, Tekke and Mevlud on Buna, Franciscan Monastery and Church of the Assumption of the Blessed Virgin Mary, Old Orthodox Church and The Cathedral of Mary Mother of the Church, The Bishop Residence, Monastery Žitomislići and the Christmas concerts. This ten out of total 19 sacral attractions poses the international tourist significance (53\%).

$>\quad$ Karađoz-bey Mosque or Zaim Hadži Mehmed-bey-Karađoz Mosque was built in 1557 and it is the largest preserved Mostar mosque. In addition to the high elegant minaret, its dome also attracts attention. The yard with harem extends to the corner of theKarađoz-Bey and Fejića Streets. This mosque is also one of the most beautiful mosques in Herzegovina. It was built according to the designs of the famous Ottoman architect, Sinan. It belongs to the same type of mosques, with identical spatial concept and identical constructive and decorative elements, as well as AladžaMosque in Foča, which also belonged to the group of the most beautiful and most famous mosques in Bosnia and Herzegovina and beyond (Mujezinović, 1998). 


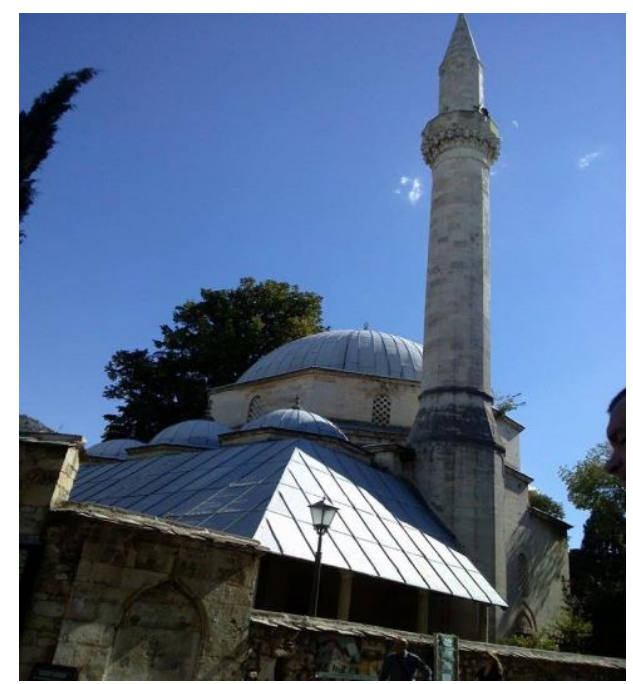

Fig. 2. Karađoz-bey Mosque inthe Mostar tourism-geographical region (Photo: Bidžan, A.)

"Karađoz-bey Mosque is a tombstone mosque with a porch under the small domes, an exterior porch with an elegant minaret, which is under the šerefa (balcony of the minaret) decorated with majestic stalactites. The central space of the mosque is bordered by walls of $1.1 \mathrm{~m}$ thickness, which make the right cube of external dimensions without the porch. The central space is covered with a dome with crown at a height of $15.9 \mathrm{~m}$ from the floor of the mosque, and the external height to the peak of the minaret is $16.5 \mathrm{~m}$. The large and fairly hollowdome of $10.7 \mathrm{~m}$ diameter leans on an octagonal tholobate. All domes on this mosque are covered with lead sheet (Fig.1). The minaret is attached to the right outer wall and its height to the peak of the minaret is $34.5 \mathrm{~m}$. The interior of the mosque is illuminated by over 25 windows, of which ten are on the side walls and five on the mihrab wall, two on the entrance wall and one on each side of the octagonal tholobate" (Hasandedić, 1980). 


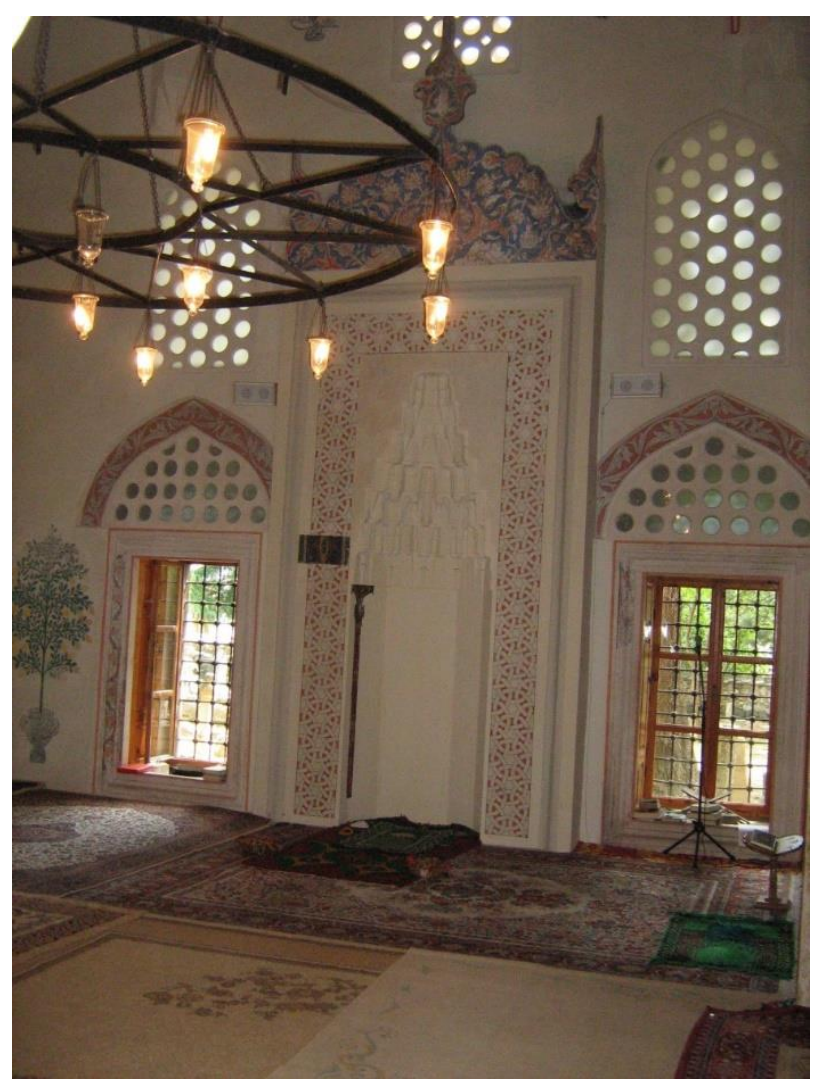

Fig. 3. Interior of Karađoz-bey Mosque, Mostar (Photo: Žunić, L.)

In the Spatial Plan of Bosnia and Herzegovina (1980), this mosque was evaluated and categorized as a site of the first (I) category of national significance (Institute for Architecture, Urban Planning and Physical Planning, Faculty of Architecture in Sarajevo, 1980). The Commission for the Preservation of National Monuments placed the Karađoz-bey Mosque on the List of National Monuments of Bosnia and Herzegovina (Commission for Preservation of National Monuments in Bosnia and Herzegovina, 2004).

In the tourist valorization, the Karađoz-bey Mosque's highest rating (5 - excellent quality and high market attractiveness) was obtained from criteria: touristgeographical position, ambience, attractiveness, compatibility, uniqueness, approach to anthropogenic tourist motives, two-season exploitation opportunities, construction/equipment and aesthetic/artistic value, and the lowest rating (4 - very good quality and very good market attractiveness) was obtained from the criteria of 
tourist attendance, and the level of utilization for tourist purposes and the representativeness. The general tourist value of this mosque is high and amounts to 4,8, which means that it has aninternational tourist significance (Table 1) (Bidžan, 2015).

Koski Mehmed-Pasha Mosque was built in 1615 and is among the most valuable monuments of Mostar and belongs to the type of Ottoman mosques with one dome. This mosque has a great significance from the urban point of view, especially for the visions as it represents an urban accent on the Neretva coast, clearly visible from both the Old Bridge and the area of MalaTepa (Zvonić, 2003).

"This mosque is one of the single-storey dome mosques with an open porch covered with three smaller domes and a stone minaret leaned on the central cube of the object. The height of the stone minaret is $28 \mathrm{~m}$ from the mosque floor, and its total height, without the peak of the minaret, is $30 \mathrm{~m}$. The mosque is airy and acoustic. In the interior of the mosque there are 25 windows of which ten are on the side walls and five on the mihrab wall, two on the entrance wall and one on each side of the octagonal tholobate" (Hasandedić, 1980).

The Spatial Plan of Bosnia and Herzegovina (1980) evaluated and categorized Koski Mehmed-Pasha Mosque (fig.2) as a monument of the I (first) category of national significance (Institute for Architecture, Urban Planning and Physical Planning, Faculty of Architecture in Sarajevo, 1980). The Commission for the Preservation of National Monuments placed Koski Mehmed-Pasha Mosque on the List of National Monuments of Bosnia and Herzegovina(Commission for Preservation of National Monuments in Bosnia and Herzegovina, 2004).

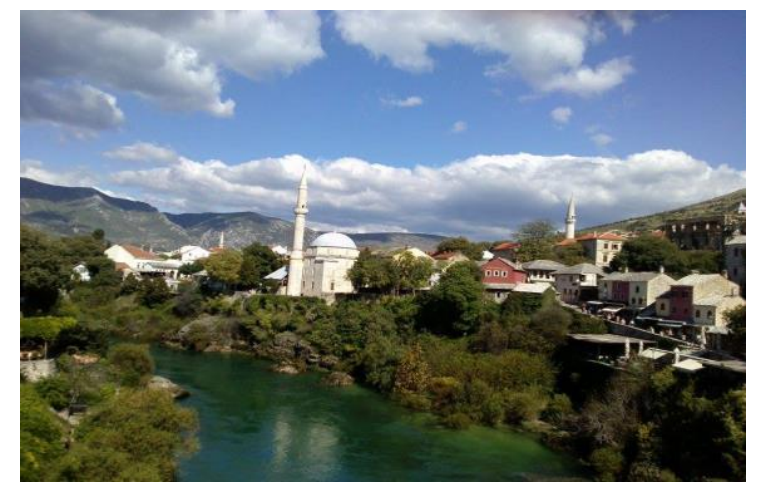

Fig. 4. Koski Mehmed-Pasha Mosque inthe Mostar tourism-geographical region (Photo: Bidžan, A.) 
In the tourist valorization, the Koski Mehmed-Pasha Mosque obtained the highest rating(5 - excellent quality and high market attractiveness) from the criteria: touristgeographical position, ambience, attractiveness,compatibility, uniqueness, access to anthropogenic tourist motives, two-season possibility of exploitation, construction 7 equipment and aesthetic/artistic value and the lowest rating (3-good quality and good market attractiveness) has gained from the criteria representativeness (Table 1) The general tourist value of this mosque is high and amounts to 4,6 , which means that it has international tourist significance (Table 1) (Bidžan, 2015).

- Franciscan Monastery and Church of the Assumption of the Blessed Virgin Mary in Šćit, municipality Prozor, was built by Franciscans probably in 15 ct., before Ottomans (Lucić, 2002). It consists of the remains of the convent building from 1857, forms and decorations exterior of the church, movable heritage and cultural landscape.

The whole monastery is, in terms of construction, consisting of:

- the remains of an old monastery building - building 1 (built in 1856, collapsed in the 80 s of the 20 th century),

- Church of the Assumption of the Blessed Virgin Mary - building 2 (rebuilt 1873.In 1881, burned in 1942, rebuilt in 1956; remodeled-restored basilica design in 1965)

- the new monastery building - building 3 (built in 1913th-1930th years, renovated and given an attic storey 1999)

- southern extension to the monastery - building 4 (construction began in 1986),

- the western extension of the monastery - building 5 (construction began in 1999),

- the souvenir shop at the extreme northern boundary of the monastery plot (built around the 1999th to 2000th year)

- landscaping of the park area with paths and sculptures. (Commission to Preserve National Monuments, Bosnia and Herzegovina)

With its artistic forms, church in Rama presents very valuable monument, and it's counted as one of the best artistic decorated sacral objects in Bosnia. There is the picture of Madonna with Christ by unknown author from 19 ct., and the picture of Djuro Seder: Sv. Franjo and the first brothers born in 1985. Over the last decade, in the monastery was created the artistic gallery with at least 100 artworks. The interesting one is the collection of 28 Rama friars' portraits (Šarčević, 2003). 


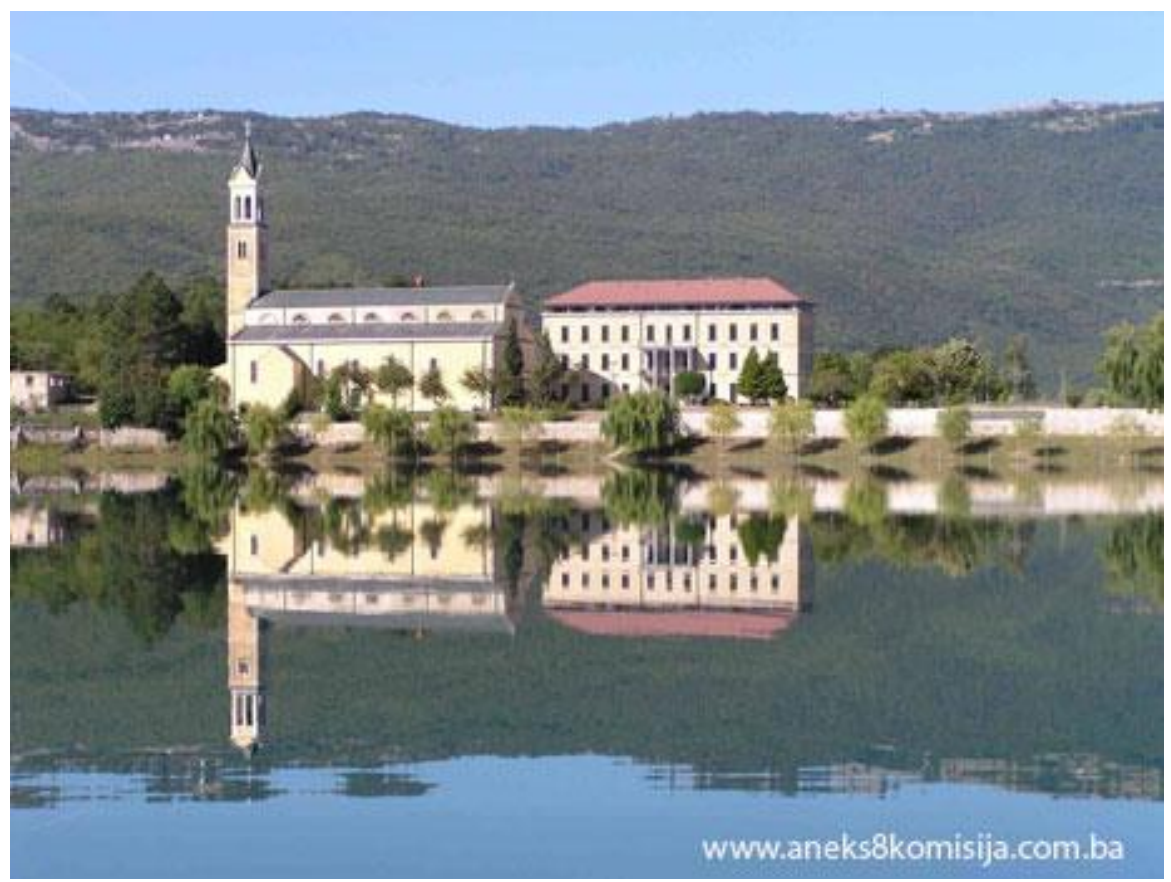

Fig. 5. Franciscan Monastery

(Source: Commission to Preserve National Monuments of Bosnia and Herzegovina)

The Spatial Plan of Bosnia and Herzegovina (1980) evaluated and categorized Franciscan Monastery and Church of the Assumption of the Blessed Virgin Mary in Śćit as a monument of the I (first) category of national significance (Institute for Architecture, Urban Planning and Physical Planning, Faculty of Architecture in Sarajevo, 1980). The Commission for the Preservation of National Monuments placed it on the List of National Monuments of Bosnia and Herzegovina (Commission for Preservation of National Monuments in Bosnia and Herzegovina, 2005).

In the tourist valorization, the Franciscan Monastery and Church of the Assumption of the Blessed Virgin Mary obtained the highest rating (5 - excellent quality and high market attractiveness) from the criteria: ambience, attractiveness, compatibility, uniqueness, possibility of tourist exploitation, construction and aesthetic/artistic value, while the lowest rating (3 -good quality and good market attractiveness) has gained from the criteria access to anthropogenic tourist motives. The general tourist value of this object is high and amounts to 4,6, which means that it has an international tourist significance (Table 1) (Bidžan, 2015). 
Old Greek Orthodox church in Mostar (Church of the Birth of the Virgin) is located on the east side of the center, in the area of Bjelušine, on the hill above Saborna Church and the old school, and it was reconstructed in 1832. An important example of sacred orthodox architecture, with the typical herzegovinian small rectangular fundament, and an inner semicircular altar apse. The orientation of the church is east-west, the entrance is on the west, while the apse is on the east side of the object. The outer dimensions of the church takes $12,25 \mathrm{~m}$ of the length and 7,75 $\mathrm{m}$ width. The church is illuminated by the four arched windows on the south and north wall of the object and the window on the apse. Above the west wall of the church there is a bell tower on the horsetail. The bell of this shape is the common feature of the churches in this area(Ševo, 2002).

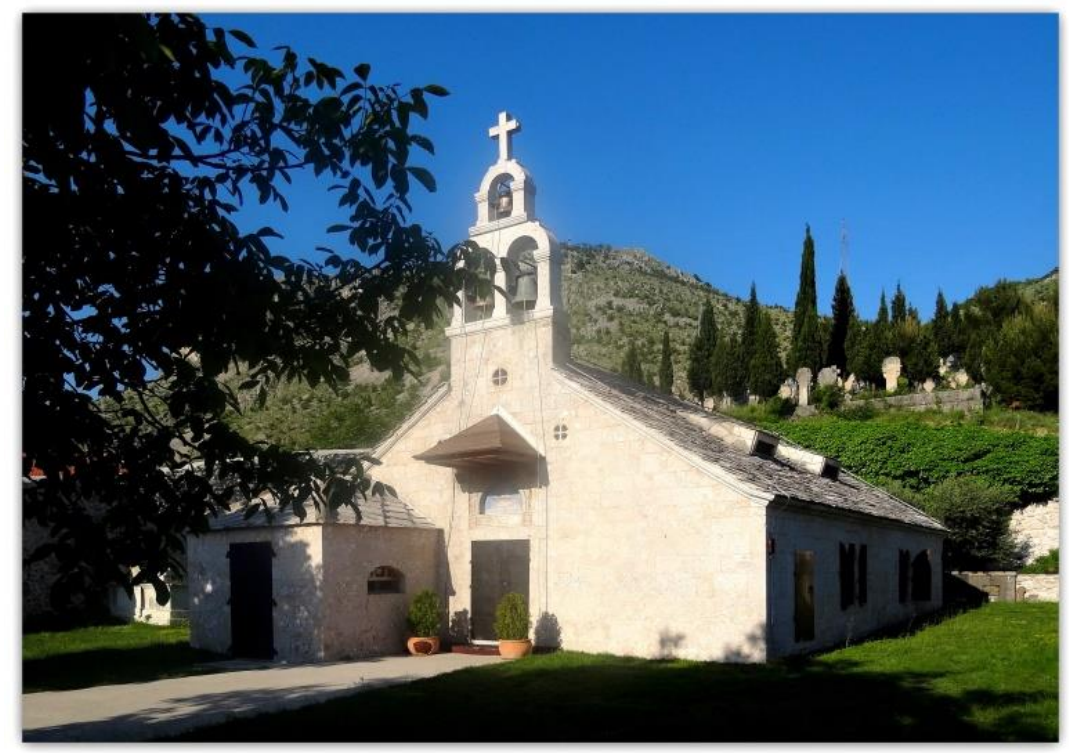

Fig. 6. Old Greek Orthodox church in Mostar (Source: Trek Earth Gallery)

The Spatial Plan of Bosnia and Herzegovina (1980) evaluated and categorized Old Greek Orthodox church in Mostar (Church of the Birth of the Virgin) as a monument of the I (first) category of national significance (Institute for Architecture, Urban Planning and Physical Planning, Faculty of Architecture in Sarajevo, 1980). The Commission for the Preservation of National Monuments placed it on the List of National Monuments of Bosnia and Herzegovina (Commission for Preservation of National Monuments in Bosnia and Herzegovina, 2003).

In the tourist valorization, The Old Greek Orthodox church in Mostar obtained the highest rating (5 - excellent quality and high market attractiveness) from the 
criteria: tourist-geographical position, ambience, attractiveness, while the lowest rating (3-good quality and good market attractiveness) has gained from the criteria of tourist attendance. The general tourist value of this object is high and amounts to 4,5, which means that it has an international tourist significance (Table 1) (Bidžan, 2015).

The Bishop's Residencel Ordinariate, Mostar is situated in the west part of the city, at Balinovac, between the former Bishop's residence and the Franciscan church. It was built in 1906 as a project of Max-Maximilian David from 1902. The building was designed in the spirit of the renaissance revival- an eclectic historical style in architecture at the transition between the 19th and the 20th century on the broader area of the Austro-Hungarian Empire (City of Mostar).

The Spatial Plan of Bosnia and Herzegovina (1980) evaluated and categorized The Bishop's Palace as a monument of the I (first) category of national significance (Institute for Architecture, Urban Planning and Physical Planning, Faculty of Architecture in Sarajevo, 1980). The Commission for the Preservation of National Monuments placed it on the List of National Monuments of Bosnia and Herzegovina (Commission for Preservation of National Monuments in Bosnia and Herzegovina, 2009).

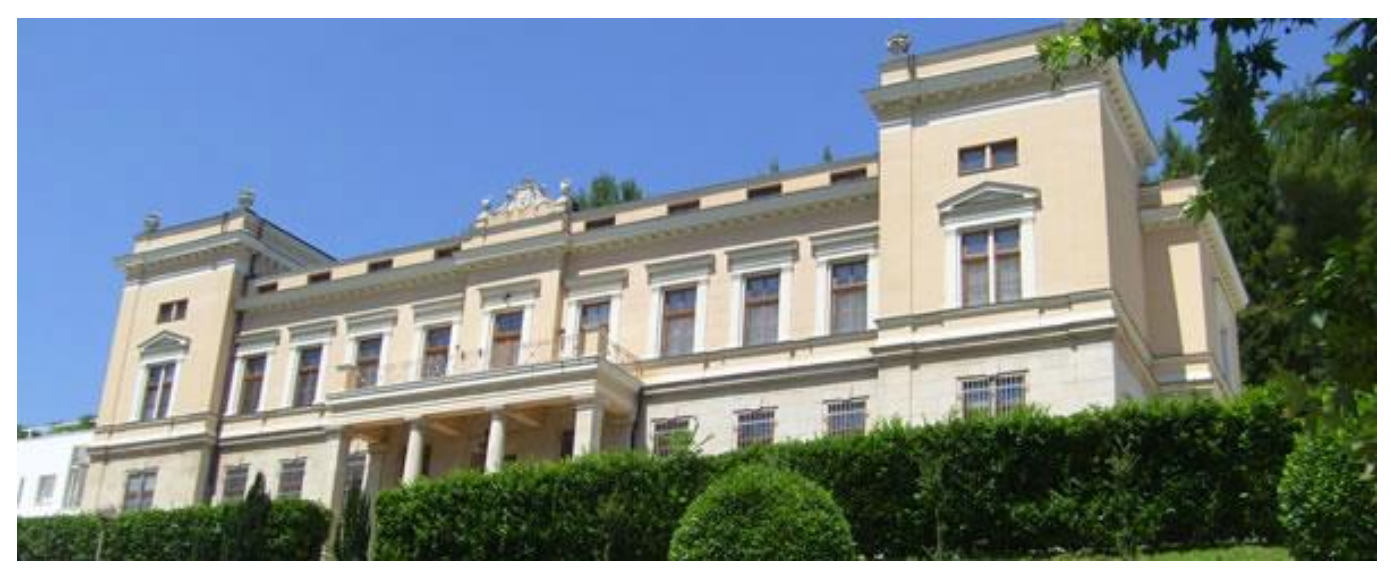

Fig. 7. The Bishop's Palace/ Residence/ Ordinariate, Mostar

(Source: City of Mostar)

In the tourist valorization, The Bishop's Residence in Mostar obtained the highest rating (5 - excellent quality and high market attractiveness) from the criteriaambience, attractiveness and artistic value, compatibility, uniqueness and 2- 
season exploitation, while the lowest rating ( 4 -very good quality and very good market attractiveness) has gained from the criteria of location, utilization, construction, the representativeness, access and the tourist attendance. The general tourist value of this object is high and amounts to 4,5, which means that it has an international tourist significance (Table 1) (Bidžan, 2015).

The Cathedral of Mary, Mother of the Church (1873), is the seat of the Mostar - Duvno Bishopric, which is one of four Catholic cathedrals in this country. The cathedral was built in the postmodern style, which is generally the main characteristic of architecture in Bosnia and Herzegovina in the second half of the twentieth and at the beginning of this century.Concrete, metal, glass and stone are materials which were used for building this monumental cathedral. In the underground part of the cathedral, there is a crypt, which serves as a chapel intended for liturgical celebrations of smaller groups. There is a bell tower and six bells which were made in the foundry Grassmayr in Innsbruck (Tourism Portal Meet Herzegovina).

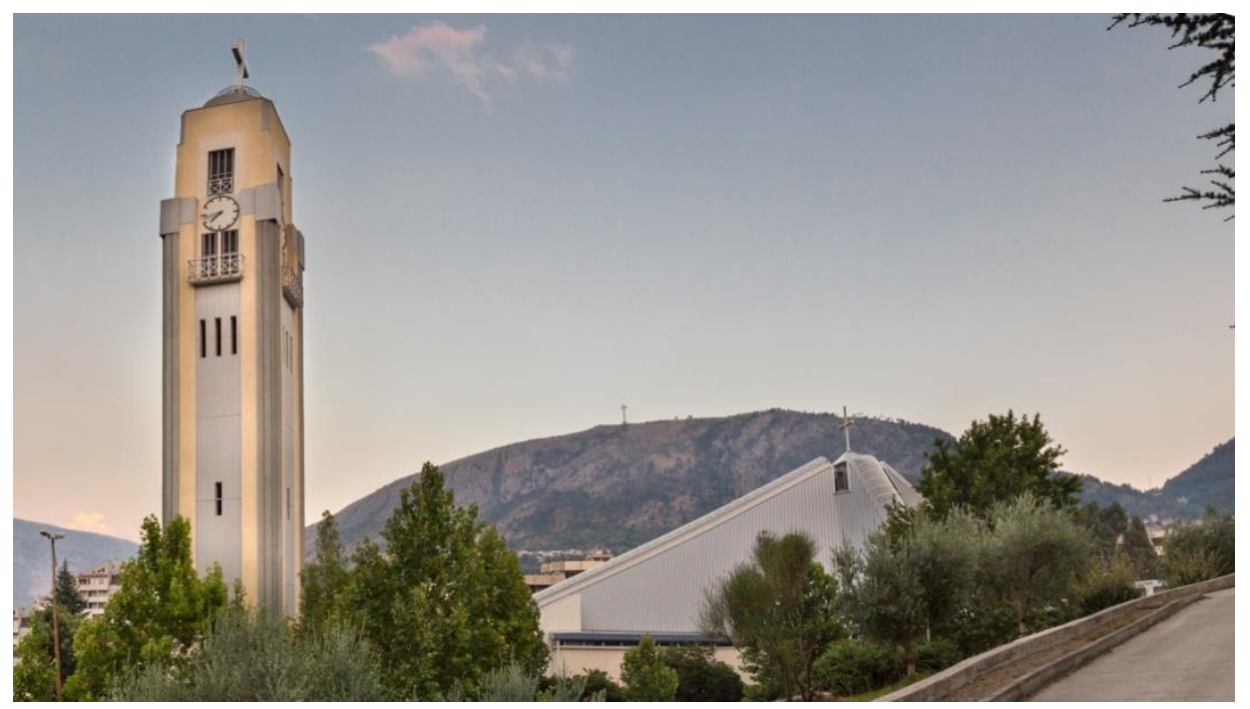

Fig. 8. The Cathedral of Mary Mother of the Church (Source: Official site of tourism agency Bosnia For You)

This church beside regular catholic festivals and holidays promote other ceremonies: 
- the ceremony of the chatedral dedication which is celebrated on the same date as the birth of bishop R. Perić in September (Neum, 1992.),

- festivity of the Maria Mother of the Church on the spiritual Monday,

- Sv. Josip, protector of Mostar - Duvno Bishopric in March (The official site of the parish office of Mary Mother of the Church).

In the tourist valorization, The Cathedral of Mary Mother of the Church obtained the highest rating (5 - excellent quality and high market attractiveness) from the criteria tourism-geographical position, ambience, attractiveness and artistic value, compatibility, uniqueness and 2-season exploitation, while the lowest rating (3.5 very good quality and very good market attractiveness) has gained from the criteria utilization and the construction. The general tourist value of this object is high and amounts to 4,5 , which means that it has an international tourist significance (Table 1) (Bidžan, 2015).

> Monastery Žitomislići, is one of the most culturally Orthodox monasteries Herzegovina from 16th century, and is dedicated to the Annunciation of the Virgin. It is situated in a valley on the road from Mostar in southern Bosnia and Herzegovina's border on the extreme western line of the old field Dubrava. In the old Hum field it represents the westernmost held Orthodox monastery. The greatest founders of monasteries were from families Miloradović and Hrabren.Žitomislići represent a gallery of religious art with ornaments of silver and gold. In 1853 water 'ćeriz' was introduced to the church covered a new vineyard was planted. In 1858 in the monastery "Divinity School" was opened and in 1859 a large building with 14 cells and two storerooms was built.Monastery Žitomislić, preserved all up to 1992 had a library with dozens of old manuscripts from the 16th and 17 th century which came to the monastery as gift or were transcribed and also a small archive of Turkish documents. Significant calligraphic works kept in the monastery are the Ćeladkovo gospel, Passionate, Panegyric, Octoid, Prayer, Virgin's miracles. During 2003 and 2005 the church, the old dormitory and the mansion were rebuilt by the Serbian Patriarch Pavle in May 2005 (Tourist Associations of Bosnia and Herzegovina).

The Spatial Plan of Bosnia and Herzegovina (1980) evaluated and categorized The Bishop's Palaceas a monument of the I (first) category of national significance (Institute for Architecture, Urban Planning and Physical Planning, Faculty of Architecture in Sarajevo, 1980). The Commission for the Preservation of National Monuments placed it on the List of National Monuments of Bosnia and Herzegovina (Commission for Preservation of National Monuments in Bosnia and Herzegovina, 2004). 


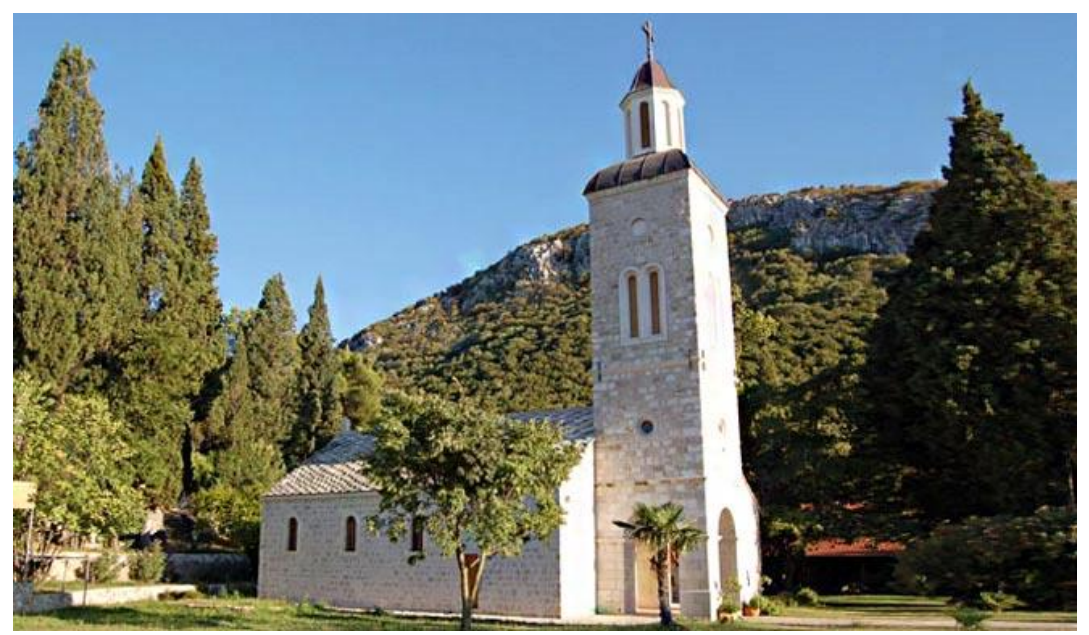

Fig. 9. Monastery Žitomislići

(Source: Tourist Associations of Bosnia and Herzegovina)

In the tourist valorization, Monastery Žitomislići in Mostar obtained the highest rating (5 - excellent quality and high market attractiveness) from the criteria location, ambience, attractiveness, compatibility, uniqueness, artistic value, 2season exploitation, while the lowest rating (4 -very good quality and very good market attractiveness) has gained from the criteria utilization, construction, the representativeness and the tourist attendance. The general tourist value of this object is high and amounts to 4,5, which means that it has an international tourist significance (Table 1) (Bidžan, 2015).

The Ensemble of the Blagaj Tekke is located on the spring of the Buna river not far from the center of Blagaj near Mostar and was built, it is assumed, immediately after the establishment of the Ottoman rule in Herzegovina, and no later than about 1520. Initially guided by the Baptist order, and later in the 18th century, after the reconstruction by the Mostar Mufti Zijaudin Ahmed-ibn-Mustafa, it will become the center for the gathering of halvets (Mujezinović, 2000).

The Tekke at the Buna River in Blagaj near Mostar is mentioned for the first time in the Travelogue of EvlijaČelebija, who traveled through this place in 1664. Čelebija states that the Mostar Mufti erected a tekke of the Halvetia order on the cliffs of the spring of the Buna in which the dervishes have friendly and scientific discussions. This information is related to Mostar Mufti, Zijudin Ahmed-ibn-Mustafa. He was born in Mostar, where he was a teacher and mufti for about 40 years. He was 
famous as a well-known connoisseur of Islamic law, and wrote several important works (Mujezinović, 2000).

The natural and architectural ensemble of Tekke and musafirhana (guesthouse) with turbe (a house-shaped structure built around the tomb) at the Buna River Spring in Blagaj near Mostar represents a valuable sacral and residential building of Islamic architecture in Bosnia and Herzegovina, with very pronounced features derived from the influence of Baroque on Ottoman architecture. In 1851, Omerpasha Latas ordered rebuilding reconstruction of the Tekke, turbe and musafirhana in Blagaj.Thirty years after the reconstruction, the Tekke was demolished by having a rock eroded on it. To this date, the musafirhana with the turbe has been preserved (Čelić, 1954). The musafirhana with the turbe is incorporated into a natural setting so that along with the cliffs, the spring of the Buna River and the mills, makes a unique unit.

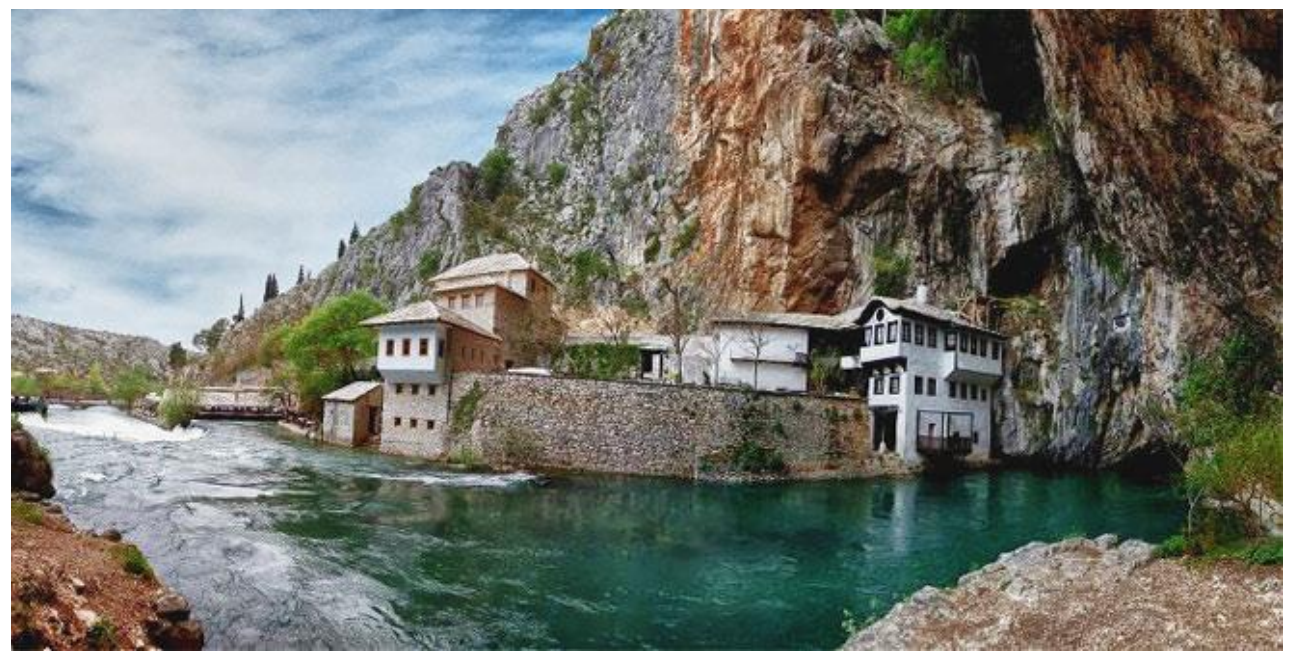

Fig. 10. The Blagaj Tekke

(Source: Web magazine Bosniaks)

The Spatial Plan of Bosnia and Herzegovina (1980) evaluated and categorized the Blagaj Tekke as a monument of the I (first) category of national significance (Institute for Architecture, Urban Planning and Physical Planning, Faculty of Architecture in Sarajevo, 1980). The Commission for the Preservation of National Monuments placed this Tekke on the List of National Monuments of Bosnia and Herzegovina (Commission for Preservation of National Monuments in Bosnia and Herzegovina, 2005). 
In the tourist valorization, the Blagaj Tekke obtained the highest rating (5 excellent quality and high market attractiveness) from the criteria: ambience, attractiveness, compatibility, uniqueness, two-season exploitation opportunities and aesthetic/artistic values and the lowest rating (3.5 - good quality and good market attractiveness) from criterion of the access to anthropogenic tourist motives. The general tourism value of this Tekke is high and amounts to 4.5 , which means that it has international tourist significance (Table 1) (Bidžan, 2015).

Religious manifestations in the Mostar tourism-geographical region are numerous, but they are predominantly of local or regional significance. One of them that stands out is the "Dovište Buna"which has international significance. In the tradition of the Bosnian-Herzegovinian Muslims, Dovište sites (Muslim places of worship) are deeply rooted and engrossed in the living being of religious and spiritual practice. This area was once a gathering place of the Bogomils, it is one of the largest Dovište sites in the area of Bosnia and Herzegovina where the number of visitors from all surrounding countries, as well as distant Emirates, often exceeds 40,000. Thus, this is a great event which is prepared and carried out by the organizers of this gathering, whose central role is the Days of Mawlid, where the Bosniaks traditionally gather to celebrate the birth of the Prophet of Allah, s.a.w.s. The central ceremony always begins with the reading of parts of the Qur'an, and in the unique ambiance of the Blagaj Tekke, imams, dervishes and sheikhs pray traditional Mawlid (Birth of the Prophet) and dhikr. In any case, this is one of the most beautiful customs of the traditional gatherings of Bosniaks. This is a place that unites the community of believers in the good and empowers their spirit to explore the preservation of their religious, cultural, traditional, linguistic and national identity in this area. "The Days of Mawlid and Zhikr" are the main annual religious and cultural manifestation of Mostar Muftiship in whose realization, apart from the Muftiship, participate the Medžlis (Majlis) of the Islamic Community of Mostar, the Karađoz-bey Madrasa, the Bosnian Cultural Community "Preporod" Mostar and the Tariqat Center of Bosnia and Herzegovina (Bidžan, 2015; Islamic community in Bosnia and Herzegovina, 2010).

All of the Dovište sites in Bosnia and Herzegovina are considered a certain phenomenon, unknown in other countries with the majority Muslim population. It speaks only of the special nature of our Bosniaks as peoples. Traditional Mawlid and Dhikr are held every other Saturday in May each year. The tradition of the annual gathering and annual Dovište in Blagaj was held until 1925. That same year its last shaykh died. Since then, the Tekke has become, more or less, just a tourist attraction, but even tourism between the two wars has not been given enough attention. However, the tradition of the Blagaj Mawlid, colloquially known as the 
Dervish Mawlid, was renewed in 1975 by the shaykh FejzulahefHadžibajrić, on behalf of the Tariqat Center, and the Mostar Mufti Seidef. Smajkić, on behalf of the institutions of the Islamic Community in Bosnia and Herzegovina. The four-year termination of tradition occurred during the war (1992-1995). According to tourist workers, the most common foreign guests in Blagaj are tourists from Malaysia and Turkey. Guests from Turkey are well informed and fascinated by the fact that the Tekke was built on the orders of the Ottoman Sultan Sulejman, who remained enchanted by the beauty of this place. The tekke is open to visitors throughout the year, and in the garden looking at the spring of the River Buna tourists can drink original Turkish coffee, tea or some refreshing drink (Bidžan, 2015, Regional and local 24-hour platform N1, 2017).

In the tourist valorization, Dovište Buna obtained the highest rating (5 - excellent quality and high market attractiveness) from the criteria: tourism-geographical position, ambience, attractiveness, compatibility, uniqueness, utilization and aesthetic/artistic values, construction, representativeness and the tourist attendance,while the lowest rating (1- inadequate quality and low market attractiveness) from criteria2-seasonal tourist exploitation because this ceremony is celebrated only once a year. The general tourism value of mawlid is high and amounts to4.5, which means that it has international tourist significance (Table 1) (Bidžan, 2015).

Christmas concertshave become the true pleasure of the Mostar tourismgeographical region. They are organized by Croatia music of Mostar and the Symphony orchestra of Mostar and Cathedral oratory choir. The ceremony takes the place atthe Croatian house of StjepanKosača or the Cathedral of Mary Mother of the Church. It has 2 aspects: a) traditional promotion of Croats from this region (Christmas songs and folklore dance and customs), and the representing international artists from the rest of the world. There is a positive trend in tourist attendance of this event (Official site of the city of Mostar).

In the tourist valorization, Christmas concerts obtained the highest rating (5 excellent quality and high market attractiveness) from the criteria: tourismgeographical position, ambience, attractiveness, compatibility, uniqueness and aesthetic/artistic values, construction, representativeness and the tourist attendance,while the lowest rating (1- inadequate quality and low market attractiveness) from criteria2-seasonal tourist exploitation because this ceremony is celebrated only once a year. The general tourism value of mawlid is high and amounts to 4.5 , which means that it has international tourist significance (Table 1) (Bidžan, 2015). 


\section{CONCLUSION}

Although there are religious sites and objects with a long tradition, spirituality and interesting architecture of all three constituent peoples and national minorities in the areas of Mostar tourism-geographical region (in this paper are described only Muslim memorials), which can be very attractive for the development of religious tourism, there is more to be done in promoting it. In Mostar region there is an exceptional potential for the development of religious tourism, but it is not adequately tourism-valued. It is a major problem that sacral objects and religious events are not sufficiently presented at the world level (only $1 / 3$ of sacral attractions have international tourist significance). The tourism of Mostar tourism-geographical region has not been sufficiently represented so far and is poorly presented on foreign markets, suggesting that tourism is not approached in the right way because the arrival of foreign guests depends on tourist operators. It is also necessary to create variety programs and web presentations in several languages, as well as brochures in foreign languages, then to establish effective co-operation between representatives of religious communities and the tourism industry, which would help promote these holy objects and sites. If we look at the world-famous religious tourism centers, which annually receive millions of tourists and which became a real commercial paradise for domestic entrepreneurs, then we can see how much religious tourism can be significant for the development of tourism, catering industry and the economy in general in that area.

Some of the guidelines for promoting religious tourism in this tourism-geographical region would be: to create more interesting programs and events that would increase tourist attention, increasing accommodation capacities, improving traffic infrastructure, improving cooperation and communication between the religious communities - the local community - the tourist community of Mostarregion, as well as revitalizing and putting into full function of religious and cultural events, furthermore building a system that would keep track of the arrivals of believers tourists coming for religious tourism, and boosting marketing (especially internet marketing) that would promote religious tourism and connect with cultural tourism.

\section{LITERATURE}

1. Bidžan A. (2012). Turističko-geografski rejoni Bosne i Hercegovine, Zbornik III Kongresa geografa Bosne i Hercegovine, Geografsko društvo u FBiH, Sarajevo. 496-512.

2. Bidžan, A. (2015). Regionalni aspekt vrednovanja turističkih potencijala Bosne i Hercegovine. Doctoral dissertation defended at the Faculty of 
Science of the University of Sarajevo. Documentation Fund of the University of Sarajevo. Sarajevo. pp. 97-100.

3. Čelić, DŽ. (1954), Neka zapažanja i iskustva u konzervatorskim pitanjima u NR Bosni i Hercegovini, Zbornik zaštite spomenika kulture / Jugoslovenski Institut za Zaštitu Spomenika Kulture, Sarajevo;

4. Commission for Preservation of National Monuments in Bosnia and Herzegovina, 2007:

http://kons.gov.ba/nacionalni_spomenici/privremena_lista/default.aspx?id=8 645\&lang Tag $=$ bs-BA $(25.02 .2019$.

5. Commission for Preservation of National Monuments in Bosnia and Herzegovina, 2018:

http://kons.gov.ba/nacionalni spomenici/privremena lista/default.aspx?id=8 645\&langTag=bs-BA (25.02.2019.)

6. Commission for Preservation of National Monuments in Bosnia and Herzegovina, 2004:

http://old.kons.gov.ba/main.php?id struct=6\&lang=1\&action=view\&id=242 4(25.02.2019.)

7. Commission for Preservation of National Monuments in Bosnia and Herzegovina, 2005:

http://old.kons.gov.ba/main.php?id_struct=6\&lang=1\&action=view\&id=255 $\underline{8}(27.02 .2019$.

8. Commission for Preservation of National Monuments in Bosnia and Herzegovina, 2005:

http://old.kons.gov.ba/main.php?id struct=6\&lang=1\&action=view\&id=280 1 (12.09.2019.)

9. Commission for Preservation of National Monuments in Bosnia and Herzegovina, 2003:

http://old.kons.gov.ba/main.php?id struct=6\&lang=1\&action=view\&id=185 $\underline{2}$ (12.09.2019.)

10. Commission for Preservation of National Monuments in Bosnia and Herzegovina, 2009:

http://old.kons.gov.ba/main.php?id_struct=6\&lang=1\&action=view\&id=307 $\underline{3}(12.09 .2019$.

11. Geić, S. (2002): Turizamikulturno-civilizacijskonaslijeđe, Veleučilište u Splitu, Split, str.45.

12. Hasandedić, H. (1980): Spomenici kulture turskog doba u Mostaru, Veselin Masleša, Sarajevo;

13. Institute for Architecture, Urban Planning and Physical Planning, Faculty of Architecture in Sarajevo, 1980: Prostorni plan Bosne i Hercegovine, Faza "B" - valorizacija; Prirodne i kulturno-historijske vrijednosti, Sarajevo; 
14. Institute for Statistics of the Federation of Bosnia and Herzegovina, 2013: http://fzs.ba/wpontent/uploads/2016/07/FZS Prezentacija Popis_2013.pdf (16.07.2018.)

15. Institute for Statistics of the Federation of Bosnia and Herzegovina, 2018: http://fzs.ba/wp-content/uploads/2018/07/Kanton-7-Hercegova\%C4\%8Dkoneretvanski-kanton.pdf (26.05.2019.)

16. Islamic community in Bosnia and Herzegovina, 2010: http://www.islamskazajednica.ba/vijesti/vijesti-arhiva/8656-mostar-danimevluda-i-zikra-2010 (16.07.2018.)

17. Kesar O. (2013): Vjerski turizam, Zagreb (Ekonomski fakultet), pristupljeno 1.9.2016. na stranici Ekonomskog fakulteta, http:/web.efzg.hr/dok/TUR/Web_Vjerski\%20turizam.pdf (16.07.2018.)

18. Lucić, Lj. (2002): Rama kroz stoljeća ,Franjevački samostan RamaŠćit, Rama-Šćit;

19. Mujezinović, M. (1998): Islamska epigrafika Bosne i Hercegovine, knjiga III, Sarajevo-Publishing, Sarajevo;

20. Mujezinović, N. (2000): Blagaj kod Mostara, Muzej Hercegovine Mostar, Hercegovina br. 11-12, Mostar;

21. Nikić, A. (1998): Rezidencija u Vukodolu, Kršni zavičaj, broj 13, Mostar.

22. Official site of the city of Mostar: http://www.turizam.mostar.ba/index.php? option=com_content $\&$ view $=$ article $\&$ id $=231 \&$ Itemid $=434 \&$ lang $=h \mathrm{hr}$ (12.09.2019.)

23. Official site of the city of Mostar: http://www.turizam.mostar.ba/index.php?option $=$ com content\&view $=$ article $\&$ id $=203 \% 3$ Abiskupskiordinarijat \&catid=41\%3 Aznamenitosti\&Itemid=424\&lang=en (13.09.2019)

24. Official site of the Tourist Associations of Bosnia and Herzegovina: https://www.visitmycountry.net/bosnia herzegovina/en/index.php/tourism/re ligious/92-turizam/vjerski/780-monastery-zitomislici (13.09.2019)

25. Official site of tourism agency Bosnia 4U: https://bosnia4u.com/2017/05/03/ catholicism/7-cathedral-of-mary-mother-of-the-church-in-mostar/ (13.09.2019)

26. Official site of tourism info- Tourism Portal Meet Herzegovina: http://www.meet-hercegovina.com/info/about-the-project.html (13.09.2019)

27. Regional and local 24-hour platform N1, 2017: http://ba.n1info.com/Vijesti/a153729/Mevlud-u-Blagaju.html (16.07.2018.)

28. Šarčević, A. (2003): Umjetnička djela crkve i franjevačkog samostana Rama - Šćit, Lijepo i sveto u susretu - Svetište Gospe ramske, str. 73.-115.

29. Ševo, Lj. (2002): Pravoslavne crkve i manastiri u Bosni i Hercegovini do 1878, Biblioteka Baština, Banja Luka, 2002. 
30. The official site of the parish office of Mary Mother of the Church http://katedrala-mostar.info/nova-katedrala-u-mostaru/ (12.09.2019.)

31. TREKEART:

https://www.trekearth.com/gallery/Europe/Bosnia_and_Herzegovina/West/B osniak-Croat/Mostar/photo1503381.htm (17.09.2019)

32. UNWTO, 2016: http://cf.cdn.unwto.org/sites/all/files/pdf/nrt_proposal_flyer14july2016-lowres.pdf(16.09.2019.)

33. Web magazine Bosniaks: http://www.bosnjaci.net/prilog.php?pid=50616 (22.09.2019)

34. Zvonić, Z. (2003): Sanacija Koski Mehmed-pašine džamije u Mostaru, Arhiv Hercegovine, Hercegovina - časopis za kulturno i istorijsko naslijeđe, br. 1112, Mostar 